\title{
INTERRELATIONSHIP BETWEEN INFORMAL TRAINING, HUMAN CAPITAL DEVELOPMENT AND INTERNATIONAL PERFORMANCE OF SMES: A LITERATURE REVIEW
}

\author{
Monika BUŽAVAITE் (iD), Renata KORSAKIENĖ (D) \\ Department of Management, Business Management Faculty, Vilnius Gediminas Technical University, \\ Sauletekio al. 11, LT-10223, Vilnius, Lithuania \\ *E-mail: monika.buzavaite@vgtu.lt
}

\begin{abstract}
Purpose - to present a deeper understanding of the interrelationships between training, human capital development and international performance in SMEs considering previous studies in this field.

Research methodology - systematic analysis and synthesis of scientific literature.

Findings - training plays a significant role in strategic planning and international orientation, forming SMEs performance. Training applied to managers and employees has a possible impact on firm's performance through improved personal performance. This study contributes to our understanding of training by presenting its role, compatibility with other processes and outcomes of it in the organization.

Research limitations - performance of SMEs could be analyzed, while the concept of performance is selected. It could help to make more relevant practical implications of the study for the company's owner or manager seeking to improve a firm's performance in a certain way. Also, more factors impacting the performance of SME's could be considered, in order to present a more comprehensive picture of this phenomenon.
\end{abstract}

Practical implications - this study reveals important insights about previously conducted studies in this field, which could be useful in order to improve further researches.

Originality/Value - two research models combining informal training, human capital, and performance of SMEs were suggested.

Keywords: international performance, SMEs, trainings, human capital development, analysis of interrelationships.

JEL Classification: M10, M13, M16, M19.

Conference topic: Contemporary Organizations Development Management.

\section{Introduction}

International performance of small and medium-sized firms (SMEs) is an evidently significant field of the research due to SMEs' crucial role in small and open countries' economy. Recent studies, analyzing this phenomenon, highlight human capital and training as important factors for international performance success. In other words, training is a quality improvement of human capital and refers to human capital development, which could be analyzed through the following characteristics such as learning, human resource development (HRD) practices or climate. HRD is a crucial topic in the management field as well because every organization has its recourses and has to implement right strategies in order to reach sustainability in the market and constantly seek improvement in the firm's performance (Del Carmen, 2018). Also, small firms are less engaged in formal training, and informality appears to be central to the emergence and operation of human resource development in small firms (Nolan \& Garavan, 2016).

The interest of scholars into countries' level of human capital is reflected in the efforts to measure human capital and its development (UNECE, 2016). Subsequently, some measurement methodologies have emerged. For instance, World Bank Human capital index (HMI) calculation methodology considers such components as kids' survival rate until the age, when formal education begins; expected learning years of school; survival of population from 15 to 60 years old, which determines the health (World Bank, 2018). Meanwhile, Mubarik et al. (2018) presented the Human capital index (HCI), which was composed by involved experts. Further study revealed that training is one of the most significant dimensions of HCI. The most important sub-dimensions of training were training in the previous workplace, technical and on the job training. These indexes show the huge significance of the training in human capital study field.

(C) 2019 Authors. Published by VGTU Press. This is an open-access article distributed under the terms of the Creative Commons Attribution (http://creativecommons.org/licenses/by/4.0/) License, which permits unrestricted use, distribution, and reproduction in any medium, provided the original author and source are credited. 
The investigations on the impact of human capital development and international performance of SMEs are scant. While some scientific gaps prevail on HRD outcomes, this paper aims to present how informal training influences human capital and how it affects the internationalization of small firms. In this investigation Resource-based view (RBV) was considered as the main theory, possibly explaining the interrelationships between training, human capital development, and internationalization in small firms. RBV theory simply highlights the availability and the knowledge of the company's human resources as the key components for the successful growth and expansion of the firm. Training is related to the growth of the company because it can expand and accumulate the human capital of the firm (Krasniqi \& Mustafa, 2016). Resources which can't be so easily repeated usually are related to human resources and serve as a potential competitive advantage (Yang, Xun, \& He, 2015). Some authors reveal HRD as a recognized source of competitive advantage (Mansor, Abu, \& Nasir, 2015). The research is grounded on systematic analysis and synthesis of scientific literature. The research delivers useful insights for future investigations in this field. After a careful literature review, two research models were developed to bring closure on what is already done in this research field and operate as a starting point for further studies. There were no significant differences noticed between training analysis at the individual and firm level. However, further studies should be oriented to the training role in the development and performance of the organization more precisely, seeking to define the more appropriate measurement of training and performance.

The paper is structured as follows: the first section presents the concept of training. The second section highlights the role of training in the context of strategic human capital management. The subsequent two sections reveal HRD relation to the performance of SMEs considering individual and firm levels. The final section concludes.

\section{The concept of training in the scientific literature}

Training can be defined as the effort to improve the knowledge or skills of the employees or managers, which are necessary for their working environment (Bager et al., 2015). Training is a part of talent management and talent development processes, which are fundamental for human resource management in the firm in order to make employees more aligned with the firm's strategies and inner culture. Such development path of the employees may involve formal and informal, cross-functional, experts prepared training, coaching or mentoring. It helps employees to develop their knowledge and skills that form the whole company's human capital (Chaudhuri et al., 2018). Nevertheless, training is a strategic sphere of business units, whose main goal is to raise the productivity of workers in new fields of knowledge, it may also improve innovation-oriented culture and support continuous improvement seeking in the organization (Calábria et al., 2018). Through training and development contribute to the quality of human capital and subsequently impact competitive advantage, this area is almost neglected in the SMEs context (Nolan \& Garavan, 2016).

The literature distinguishes two main types of training: formal and informal (Hollow \& Vik, 2016). Formal training is oriented to specific qualification attainment and thus, can be distinguished to internal and external training in line with the organizer of the training. Informal training is usually defined as unstructured, mainly oriented to learning through experience and not organized by training institution. In the scientific literature, this type of training can also be referred to on-the-job learning, workplace training or learning by doing. As compared to formal training, informal training is not planned and obtained by doing everyday activities, while formal training implements arranged exercises (Hollow \& Vik, 2016). Informal training's principal ways are on-the-job learning, learning from others and reading books. On-the-job learning is oriented to job function. Hence learning from others implies being aware of job environment changes and having the willingness to follow approaches of other successful workers. In addition, reading books is the most common way of self-learning, which helps to prepare for actual tasks (Jiang et al. 2018).

Del Carmen (2018) stressed out that training is usually associated with investment in human resources, whose beget are primarily reduced when a firm faces financial struggles. Nevertheless, this move of the firm is not always well weighted, because training is the source of innovations, best practices, and accumulated knowledge. Training is fundamental for the firm's growth because it contributes to the human and intellectual capital of the firm. Diniz \& Vale (2016) emphasized the importance of investment in human capital by training because it increases work satisfaction of employees and increases performance due to higher competencies developed by the employees.

In a small business, context training is described as informal and short-term oriented. Subsequently, the studies suggest that small firms almost neglect formal training analysis and do not attempt to adopt a systematic approach to training (Nolan \& Garavan, 2016). The explanation resides in the fact that owners of the firms perceive formal training as additional costs. Moreover, the high uncertainty faced by small firms leads to a shorter time horizon. Contrary to the larger firms, SMEs are not capable to experience benefits of training in a long-term perspective. Thus, informal training appears to be less costly and is consistent with the overall strategic orientation of the firm. Thus, in the next section, we are going to analyze training in the context of strategic human resource management.

\section{Methodology}

Systematic analysis and synthesis of the scientific literature were applied in this study. Relevant articles were identified by using keywords of the topic in the Web of Science database. After careful analysis of the articles, common elements 
of the study models were compounded into the aggregated models, which illustrate relationships between investigated constructs. The first developed model reveals the interrelationships of business strategy, training, human capital, and performance. The second presents interrelationships of training, human capital, and international business orientation performance. Also, studies focused on training were analyzed trough main factors, its relationship to the firm's performance and factors impacting the performance of the firm were distinguished. These findings were gathered into informative tables.

\section{Strategic human resource management and training}

Strategic human resource management (SHRM) emphasizes planned human resource (HR) activities contributing to the strategic goals of organizations. Apparently, HR system includes various HR practices which influence performance-related outcomes. Thus, the human capital of the firm is created and maintained by using a number of HR practices (Boon, Eckardt, Lepak, \& Boselie, 2018). While SHRM distinguishes the relationship between HR practices, strategic goals of the firm and firm's performance, training and development significantly influence employees' and top managers' human capital and consequently performance of the firm (Figure. 1).

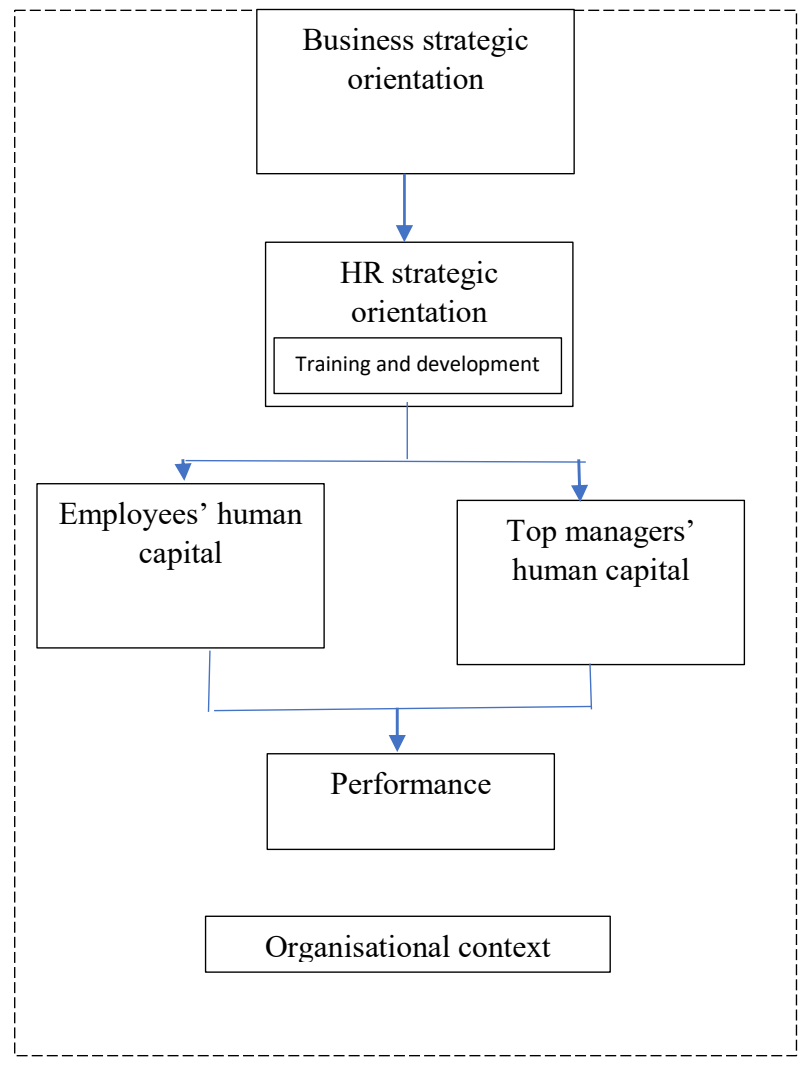

Figure 1. Interrelationships of business strategy, training, human capital and performance.

(source: developed by authors)

Notably, the resource-based view is seen as the predominant theory in SHRM area (Nolan \& Garavan, 2016). Firstly, the studies suggest that firm-specific resources are key drivers of competitive advantage. Thus, human resources are perceived as valuable resources. Secondly, grounded on the strategic management field, the literature emphasizes that HR systems are the source of competitive advantage. Meanwhile, some scholars suggest that in a given context of the firm HR systems encourage the behavior of employees. Training and development not only help employees to adapt to the fast-changing environment of the firm, but also to improve personal performance and subsequently, the performance of the whole firm (Mansor et al., 2015). Finally, training is related to human capital development and adds value to the company. Though the impact of training on the firm's performance is obvious, not all firms have measures on it (Riley, Michael, \& Mahoney, 2017). Apparently, small firms demonstrate a flexible and informal approach to strategy formulation and thus, are tended to revise the strategy. The studies demonstrate that the strategy process in a small business context aims to match human resource practices with short-term priorities instead of long-term priorities (Nolan \& Garavan, 2016). These insights let us suggest focusing on the interrelationships between training and development, human capital and strategic orientation. 

and international performance of SMEs: a literature review

Figure 2 illustrates how training influences employees' and managers' human capital and subsequently international orientation of the firm. Various scientific theories suggest different variables of training. Considering informal learning theory, informal learning initiatives can be formed by such factors as attitudes of employees and technology, integrated into the learning process of SMEs (Admiraal \& Lockhorst, 2009). Informal learning can be described trough work environment characteristics, supervisor's support, (di)satisfaction with learning, sources and methods of learning (Coetzer, 2007). Saunders et al. (2014) emphasize learning orientation as an important factor in informal learning. Meanwhile, action learning theory highlights action in the owner-managers, reflection, and engagement with the social network context (Clarke, Thorpe, Anderson, \& Gold, 2006). Hence, experiential learning could be expressed through such variables as the importance of training, learning strategies of learning (Birdthistle, 2006). Harris (2009) distinguishes individual and organizational learning and tacit knowledge transfer to the organization. Finally, workplace learning combines informal and incidental learning (Rowden, 2002).

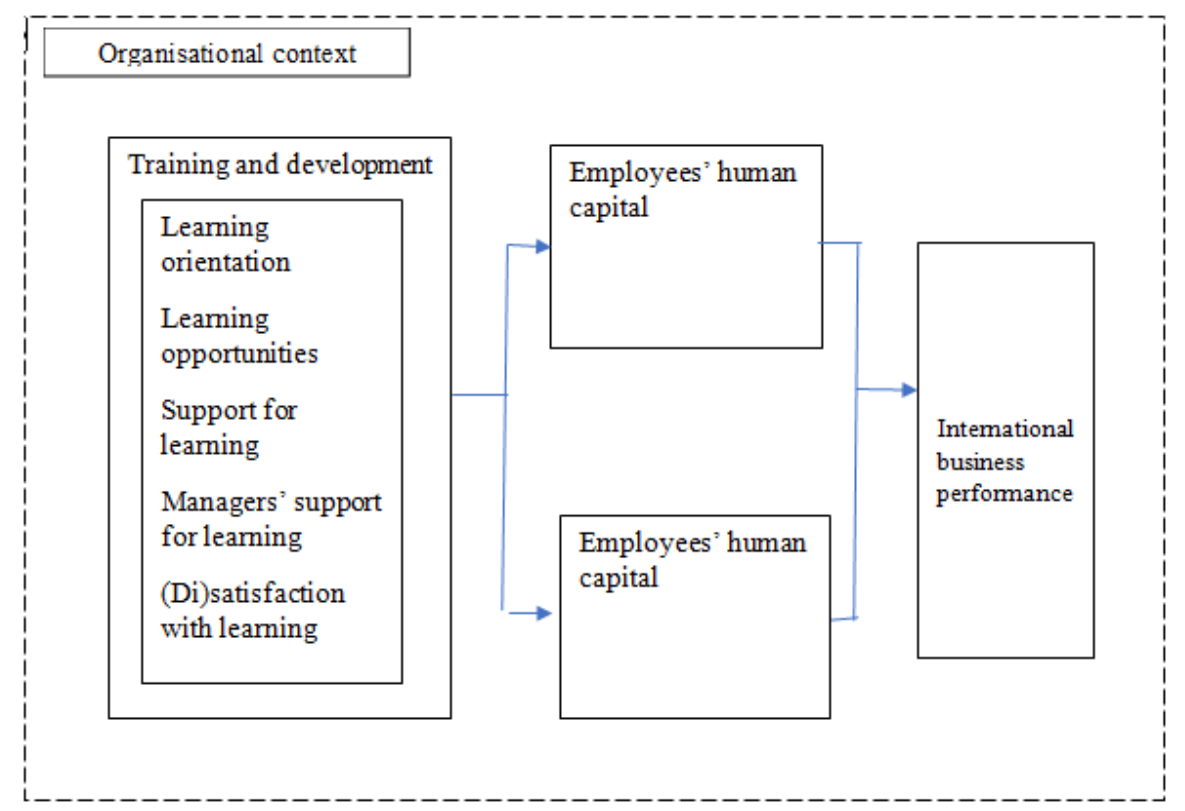

Figure 2. Interrelationships of training, human capital and international business performance. (source: developed by authors)

Training and development strategies applied by the firm contribute to human capital. The concept of human capital refers to any knowledge or the acquired characteristics of a person which contribute to his or her economic productivity (Diop, Pascot, Mahmoud, \& Mbibi, 2013). Consequently, human capital shapes the orientation of the business, which is related to its performance and prediction of further success to the company. International business performance can be measured through such variables as international intensity, perceived satisfaction in the international activity and internationalization results (Hernández-Perlines \& Xu, 2018). In the literature, this concept can be also identified as an orientation toward business expansion or orientation toward international development (Suzuki \& Okamuro, 2016). While human capital influences the international performance of the firm, in the next section we are going to observe some observations considering firm level and individual level performance.

In conclusion, a couple of approaches to training could be highlighted. Training can be analyzed as a part of HR strategic orientation directed to employees' and managers' human capital, seeking to improve the firm's performance. This classical approach links training to HR and business strategic orientation. The second approach is controversial by claiming that training determines business international performance. Different approaches towards training emphasize training's importance for a firm's strategic management and performance and also form necessity for deeper investigations aiming to present more determined training's role in the firm's management and its possible outcomes.

\section{Interrelations of human capital development and performance}

The study performed by Krasniqi and Mustafa (2016) revealed that training is one of the main factors influencing the growth of the small company( see Table 1). In addition, the study demonstrated that SMEs, which provide training at the workplace, are more likely to experience significant growth as compared with other firms, which do not implement such training. Mansor et al. (2015) confirmed the hypothesis that training and human capital development is related to the small firm's sustainability in the market. Firstly, training help employees to obtain necessary knowledge, skills or attitudes and improve personal performance. Consequently, the increase in personal performance positively contributes 

and international performance of SMEs: a literature review

to the sustainability and performance of the firm. Ciriaci (2017) analyzed intangible resources and found that investment in training triggers innovativeness in the firm. While a return of investment in training was higher in larger firms, it was significant in small firms and was not related to the level of the workers' knowledge. Wan Hooi and Sing Ngui (2014) identified organizational learning (OL) as the mediator between human capital management and organizational performance. The concept of organizational learning is interrelated to training. Organizational learning involves gaining and developing knowledge in the organization. The scholars concluded that small companies should empower OL by HR practices in order to improve organization performance (Wan Hooi \& Sing Ngui, 2014). Meanwhile, Bilgin, Marco Lau, and Demir (2012) couldn't confirm that training at the workplace affects the performance of the firm as well as expansion through exporting. The study considered the profit per worker as the performance of the firm.

Table 1. The relationship between training at firm level and performance of SMEs (source: compiled by authors)

\begin{tabular}{|l|l|l|l|l|}
\hline \multicolumn{1}{|c|}{ Training } & \multicolumn{1}{|c|}{ The main factors } & $\begin{array}{l}\text { Relationship with the per- } \\
\text { formance of firm }\end{array}$ & \multicolumn{1}{c|}{$\begin{array}{c}\text { The factors contributing to per- } \\
\text { formance }\end{array}$} & \multicolumn{1}{c|}{ Author } \\
\hline $\begin{array}{l}\text { As dimension of } \\
\text { Human capital } \\
\text { construct. }\end{array}$ & $\begin{array}{l}\text { Education, training, } \\
\text { gender, age. }\end{array}$ & $\begin{array}{l}\text { Trainings more likely } \\
\text { boost the performance of } \\
\text { the company. }\end{array}$ & $\begin{array}{l}\text { Proportion of employees and } \\
\text { managers with at least high } \\
\text { school education. Incidence of } \\
\text { employee and managers training. }\end{array}$ & $\begin{array}{l}\text { Krasniqi } \\
\text { and Mustafa } \\
(2016)\end{array}$ \\
\hline $\begin{array}{l}\text { As training and } \\
\text { development con- } \\
\text { struct. }\end{array}$ & $\begin{array}{l}\text { Training and develop- } \\
\text { ment, compensation } \\
\text { and rewards. }\end{array}$ & $\begin{array}{l}\text { Training and develop- } \\
\text { ment; compensation and } \\
\text { rewards are positively sus- } \\
\text { taining the SME's organi- } \\
\text { zational performance. }\end{array}$ & $\begin{array}{l}\text { Authors don't specify measures } \\
\text { of factors. }\end{array}$ & $\begin{array}{l}\text { Mansor } \\
\text { et al. (2015) }\end{array}$ \\
\hline $\begin{array}{l}\text { As independent } \\
\text { variable. }\end{array}$ & $\begin{array}{l}\text { Training, marketing } \\
\text { and design. }\end{array}$ & $\begin{array}{l}\text { Training has a positive im- } \\
\text { pact on a firm's innovative } \\
\text { sales. }\end{array}$ & $\begin{array}{l}\text { Firm's decision on whether or } \\
\text { not to engage in training, invest- } \\
\text { ments in training. }\end{array}$ & $\begin{array}{l}\text { Ciriaci } \\
(2017)\end{array}$ \\
\hline $\begin{array}{l}\text { As dimension of } \\
\text { organizational } \\
\text { learning capability } \\
\text { (OLCAP). }\end{array}$ & $\begin{array}{l}\text { Human resource prac- } \\
\text { tices, organizational } \\
\text { learning capability. }\end{array}$ & $\begin{array}{l}\text { OLCAP has a positive im- } \\
\text { pact on organizational per- } \\
\text { formance. }\end{array}$ & $\begin{array}{l}\text { Managerial commitment to } \\
\text { learning, systems perspective, } \\
\text { openness and experimentation, } \\
\text { knowledge transfer and integra- } \\
\text { tion. }\end{array}$ & $\begin{array}{l}\text { Wan Hooi } \\
\text { and Sing } \\
\text { Ngui (2014) }\end{array}$ \\
\hline $\begin{array}{l}\text { As independent } \\
\text { variable. }\end{array}$ & $\begin{array}{l}\text { Human resource qual- } \\
\text { ity, State-owned en- } \\
\text { terprise, training, } \\
\text { skilled/unskilled } \\
\text { workers. }\end{array}$ & $\begin{array}{l}\text { Formal training has a neg- } \\
\text { ative effect on a firm's } \\
\text { productivity. }\end{array}$ & $\begin{array}{l}\text { Percentage of workers who re- } \\
\text { ceived formal training from the } \\
\text { firm. }\end{array}$ & $\begin{array}{l}\text { Bilgin et al. } \\
(2012)\end{array}$ \\
\hline
\end{tabular}

Peter et al. (2018) conducted the study which did not disclose the evidence that training is positively related to the performance of a small firm. However, training can alleviate the implementation of innovations among owners of small business. Efobi and Orkoh (2018) specified entrepreneurship training as having an impact on the firm's performance. This kind of training demonstrates two positive aspects because an entrepreneur can develop personal skills and knowledge and later spread it to his/her subordinates. The scholars observed the considerably low impact of training on the revenue increase in the company. Lajqi \& Krasniqi (2017) empirically confirmed that training is the only factor of examined human capital variables, which had a positive impact on an entrepreneur's growth aspirations. These results suggest that training has become more exploited in modern organization with the purpose to increase employees' growth. Bager et al. (2015) noticed that young managers, who recently started their management career, more likely select training related to the firm's growth and along with the age of manager interest in the training decrease.

Conducted analysis disclosed no evidence revealing major differences between training at the firm and individual levels. In more cases, training was analyzed as an independent variable than as a dimension of other constructs. This confirms the importance and high focus of scholars to the training as the object of their studies. Almost all studies validated training's positive impact on firm performance. Training was measured as a proportion of employees and managers with certain education level or who received formal training from the firm, the decision of engagement in training, evaluation of training, commitment to learning or enrollment into training. It exposes that scholars have no agreement on a certain measurement of training. Also, the performance of the company was measured differently. Overall, the training topic in scientific literature requires deeper analysis in terms of measurement, role, and impact on certain key performance indicators (KPI). 

and international performance of SMEs: a literature review

Table 2. The relationship between training at individual level and performance of SMEs (source: compiled by authors)

\begin{tabular}{|l|l|l|l|l|}
\hline \multicolumn{1}{|c|}{ Training } & \multicolumn{1}{|c|}{ The main factors } & \multicolumn{1}{|c|}{$\begin{array}{c}\text { Relationship with } \\
\text { performance of firm }\end{array}$} & \multicolumn{1}{c|}{$\begin{array}{c}\text { The factors contributing } \\
\text { to performance }\end{array}$} & \multicolumn{1}{c|}{ Author } \\
\hline $\begin{array}{l}\text { As independent } \\
\text { variable. }\end{array}$ & $\begin{array}{l}\text { Authors don't men- } \\
\text { tion/specify other fac- } \\
\text { tors. }\end{array}$ & $\begin{array}{l}\text { Training assistance has } \\
\text { positive relation to inno- } \\
\text { vative performance of } \\
\text { SMEs. }\end{array}$ & $\begin{array}{l}\text { Benefits from government train- } \\
\text { ing assistance. }\end{array}$ & $\begin{array}{l}\text { Peter et al. } \\
(2018)\end{array}$ \\
\hline $\begin{array}{l}\text { As independent } \\
\text { variable. }\end{array}$ & $\begin{array}{l}\text { Training for entrepre- } \\
\text { neurs. }\end{array}$ & $\begin{array}{l}\text { Training has slight posi- } \\
\text { tive impact on the com- } \\
\text { pany. }\end{array}$ & $\begin{array}{l}\text { Standard evaluation of training by } \\
\text { entrepreneurs. }\end{array}$ & $\begin{array}{l}\text { Efobi and } \\
\text { Orkoh } \\
(2018)\end{array}$ \\
\hline $\begin{array}{l}\text { As dimension of } \\
\text { human capital } \\
\text { construct. }\end{array}$ & $\begin{array}{l}\text { Education, experi- } \\
\text { ence, training of en- } \\
\text { trepreneur. }\end{array}$ & $\begin{array}{l}\text { Training of entrepreneur } \\
\text { has a positive impact on } \\
\text { growth aspirations of en- } \\
\text { trepreneur }\end{array}$ & $\begin{array}{l}\text { If the entrepreneur has a univer- } \\
\text { sity degree or more, if entrepre- } \\
\text { neur had management training in } \\
\text { the previous three years, growth } \\
\text { aspirations of the entrepreneur, it } \\
\text { positively affects growth aspira- } \\
\text { tions of the entrepreneur. }\end{array}$ & $\begin{array}{l}\text { Lajqi \& } \\
\text { Krasniqi } \\
(2017)\end{array}$ \\
\hline $\begin{array}{l}\text { As independent } \\
\text { variable. }\end{array}$ & $\begin{array}{l}\text { Management position, } \\
\text { experience, training, } \\
\text { education, working } \\
\text { hours per week. }\end{array}$ & $\begin{array}{l}\text { Formal growth-oriented } \\
\text { training programs for } \\
\text { SME managers related to } \\
\text { improved growth perfor- } \\
\text { mance. }\end{array}$ & $\begin{array}{l}\text { Enrolled into training programs } \\
\text { and not enrolled were compared. }\end{array}$ & $\begin{array}{l}\text { Bager } \\
\text { et al. } \\
(2015)\end{array}$ \\
\hline
\end{tabular}

\section{Conclusions}

The research extends prevailing literature. Firstly, this study contributes to the theory by presenting two research models, which suggest two different approaches to how training and development determine international business performance in terms of organizational context. These models help to reveal the main variables and relationships among it in the previously conducted study, which establishes the starting point for future studies.

Secondly, the concept of training varies among the scholars and there is no agreement on the role of training in the organization. Training occupies an important role in human resource management, which could be oriented to managers or employees. Human resource management strategy is integrated into business strategies, such as expanding or boosting the performance of the firm and training helps to link this strategy to the performance. Future studies should be oriented to determine more concrete training's role in the firm's management and its possible outcomes.

In addition, the analysis of previously conducted studies on interrelationships between training, human capital development, and performance of the firm revealed that these relations are investigated reasonably, and several studies empirically confirmed the positive impact of training and development on the firm's performance. The other remark is regarding a variety of the measurement of training and performance of the company, which makes studies uncomparable. We did not disclose significant differences between training at individual and organizational levels. The studies which focused on organization level mostly analyzed such variables of human capital as, training, development, learning constructs, organizational performance. Meanwhile, training at an individual level was mainly investigated as an independent variable and considered as having an impact on the performance of the whole firm. Recommendations for further studies would be related to focusing on the more appealing measurement of training and performance than training levels.

Finally, despite our comprehensive analysis, some limitations can be mentioned. The limitations of this study are related to the analysis object, which was interrelationships between training, human capital, and performance of the small firm. Notably, the performance of the firm is a vast study area, which may refer to international expansion, international orientation or improved financial results. Further studies could be more focused on the firm's performance and chose a more specific concept of performance for the deeper analysis. Also, only certain impact factors of performance such as training and development were analyzed. Future studies could consider a wider range of impact factors of firm's performance. In addition, a higher number of similar studies could be analyzed for more reliable results.

\section{Disclosure statement}

The authors ensure that there are no financial, professional, or personal conflicts of interest to disclose. 


\section{References}

Admiraal, W., \& Lockhorst, D. (2009). E-Learning in small and medium-sized enterprises across Europe. International Small Business Journal: Researching Entrepreneurship, 27(6), 743-767. https://doi.org/10.1177/0266242609344244

Bager, T. E., Jensen, K. W., Nielsen, P. S., \& Larsen, T. A. (2015). Enrollment of SME managers to growth-oriented training programs. International Journal of Entrepreneurial Behavior \& Research, 21(4), 578-599. https://doi.org/10.1108/IJEBR-122014-0224

Bilgin, M. H., Marco Lau, C. K., \& Demir, E. (2012). Technology transfer, finance channels, and SME performance: New evidence from developing countries. The Singapore Economic Review, 57(03), 1250020. https://doi.org/10.1142/S0217590812500208

Birdthistle, N. (2006). Training and learning strategies of family businesses: an Irish case. Journal of European Industrial Training, 30(7), 550-568. https://doi.org/10.1108/03090590610704402

Boon, C., Eckardt, R., Lepak, D. P., \& Boselie, P. (2018). Integrating strategic human capital and strategic human resource management. The International Journal of Human Resource Management, 29(1), 34-67. https://doi.org/10.1080/09585192.2017.1380063

Calábria, F. A., Melo, F. J. C. de, Albuquerque, A. P. G. de, Jerônimo, T. de B., \& Dumke de Medeiros, D. (2018). Changing the training paradigm for learning: A model of human capital development. Energy \& Environment, 29(8), 1455-1481. https://doi.org/10.1177/0958305X18779580

Chaudhuri, S., Hirudayaraj, M., \& Ardichvili, A. (2018). Borrow or grow: An overview of talent development/management practices in Indian IT organizations. Advances in Developing Human Resources, 20(4), 460-478. https://doi.org/10.1177/1523422318803345

Chow, I. H. S., \& Liu, S. S. (2009). The effect of aligning organizational culture and business strategy with HR systems on firm performance in Chinese enterprises. The International Journal of Human Resource Management, 20(11), 2292-2310. https://doi.org/10.1080/09585190903239666

Ciriaci, D. (2017). Intangible resources: the relevance of training for European firms' innovative performance. Economia Politica, 34(1), 31-54. https://doi.org/10.1007/s40888-016-0049-8

Clarke, J., Thorpe, R., Anderson, L., \& Gold, J. (2006). It's all action, it's all learning: action learning in SMEs. Journal of European Industrial Training, 30(6), 441-455. https://doi.org/10.1108/03090590610688825

Coetzer, A. (2007). Employee perceptions of their workplaces as learning environments. Journal of Workplace Learning, 19(7), 417-434. https://doi.org/10.1108/13665620710819375

Del Carmen, M. (2018). Factorial analysis of the elements that compose the training in the small and medium enterprises of the Industrial sector. Management, 22(2), 42-59. https://doi.org/10.2478/manment-2018-0022

Diniz, F., \& Vale Leitao, H. (2016). Entrepreneurship and Social Innovation in Training and Human Capital Development: the Case of the Bank Palmas. Economy of Region, 865-874. https://doi.org/10.17059/2016-3-21

Diop, B., Pascot, D., Mahmoud, S., \& Mbibi, A. (2013). Theoretical Framework of Human Capital Development of SMEs: The Context of an ERP Project. Journal of Enterprise Resource Planning Studies, 2013. https://doi.org/10.5171/2013.256196

Efobi, U., \& Orkoh, E. (2018). Analysis of the impacts of entrepreneurship training on growth performance of firms. Journal of Entrepreneurship in Emerging Economies, 10(3), 524-542. https://doi.org/10.1108/JEEE-02-2018-0024

Harris, R. J. (2009). Improving tacit knowledge transfer within SMEs through e-collaboration. Journal of European Industrial Training, 33(3), 215-231. https://doi.org/10.1108/03090590910950587

Hernández-Perlines, F., \& Xu, W. (2018). Conditional mediation of absorptive capacity and environment in international entrepreneurial orientation of family businesses. Frontiers in Psychology, 9. https://doi.org/10.3389/fpsyg.2018.00102

Hollow, M., \& Vik, P. (2016). Another step up the ladder or another foot in the grave? Re-evaluating the role of formal and informal training in the career development process within Barclays Bank, 1945-1980. Management \& Organizational History, 11(4), 345-363. https://doi.org/10.1080/17449359.2016.1230068

Jiang, N., Sumintono, B., Perera, C. J., Harris, A., \& Jones, M. S. (2018). Training preparation and the professional development of principals in Henan Province, China: formal and informal learning. Asia Pacific Education Review, 19(1), $41-51$. https://doi.org/10.1007/s12564-017-9513-6

Krasniqi, B. A., \& Mustafa, M. (2016). Small firm growth in a post-conflict environment: the role of human capital, institutional quality, and managerial capacities. International Entrepreneurship and Management Journal, 12(4), 1165-1207. https://doi.org/10.1007/s11365-016-0384-9

Lajqi, S., \& Krasniqi, B. A. (2017). Entrepreneurial growth aspirations in challenging environment: The role of institutional quality, human and social capital. Strategic Change, 26(4), 385-401. https://doi.org/10.1002/jsc.2139

Mansor, M. F., Abu, N. H., \& Nasir, H. (2015). The powerful of training; Development and compensation; rewards in sustaining small medium enterprises performance. Advanced Science Letters, 21(5), 1426-1429. https://doi.org/10.1166/asl.2015.6057

Mubarik, M. S., Chandran, V. G. R., \& Devadason, E. S. (2018). Measuring human capital in small and medium manufacturing enterprises: What matters? Social Indicators Research, 137(2), 605-623. https://doi.org/10.1007/s11205-017-1601-9

Nolan, C. T., \& Garavan, T. N. (2016). Human resource development in SMEs: A systematic review of the literature. International Journal of Management Reviews, 18(1), 85-107. https://doi.org/10.1111/ijmr.12062

Peter, F. O., Oladele, P., Adegbuyi, O., Olokundun, A. M., Peter, A. O., Amaihian, A. B., ... Salau, O. P. (2018). Data set on training assistance and the performance of small and medium enterprises in Lagos, Nigeria. Data in Brief, 19, 2477-2480. https://doi.org/10.1016/j.dib.2018.07.023 
Bužavaitè, M.; Korsakiene, R. 2019. Interrelationship between informal training, human capital development and international performance of SMEs: a literature review

Riley, S. M., Michael, S. C., \& Mahoney, J. T. (2017). Human capital matters: Market valuation of firm investments in training and the role of complementary assets. Strategic Management Journal, 38(9), 1895-1914. https://doi.org/10.1002/smj.2631

Rowden, R. W. (2002). The relationship between workplace learning and job satisfaction in U.S. small to midsize businesses. Human Resource Development Quarterly, 13(4), 407-425. https://doi.org/10.1002/hrdq.1041

Saunders, M. N., Lewis, P., \& Thornhill David Gray, A. E. (n.d.). SME innovation and learning: the role of networks and crisis events. Retrieved from https://gala.gre.ac.uk/id/eprint/19691/3/19691 GRAY_SME_Innovation_and_Learning_2014.pdf

Suzuki, S., \& Okamuro, H. (2016). Determinants of academic startups' orientation toward international business expansion. Administrative Sciences, 7(1), 1. https://doi.org/10.3390/admsci7010001

UNECE (2016). Guide on measuring human capital. The Task Force on Measuring Human Capital. United Nations New York and Geneva, 2016

Wan Hooi, L., \& Sing Ngui, K. (2014). Enhancing organizational performance of Malaysian SMEs. International Journal of Manpower, 35(7), 973-995. https://doi.org/10.1108/IJM-04-2012-0059

World Bank (2018). Methodology for a World Bank human capital index. Background Paper to the 2019 World Development Report.

Yang, T., Xun, J., \& He, X. (2015). British SMEs' e-commerce technological investments and firm performance: an RBV perspective. Technology Analysis \& Strategic Management, 27(5), 586-603. https://doi.org/10.1080/09537325.2015.1019453 